\title{
ステレオ投影法とその金屬學への應用 (III)
}

\section{山 本 美 喜 雄*}

\section{VIII. 優 越 方 位}

壓延の如き變形過程を經た金屬に於ける䋨晶粒の方 位法，その物質の物理的性筫儿影響を與へる點に於て， 基礎的な重要性をるつるのである.絬晶粘の方位が統 計的飞出鱗目を場合にのみ，物理的性質は總ての方向

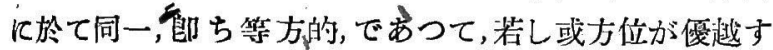
る (preferred) 場合には, 等軸型の金蛊に於てさへ，性質 纺方向性，即ち異方性 (anisotropy)，を示す。ステレオ投 影乃至極點圖はX線寫真を結晶方向の分布江依つて解 橉する方法として，又測定結果を正確且つ定量的江表 示する手段として，最も優れたるのである．この投影が 1924 年 Wever ${ }^{(28)}$ 亿体つて始めて斯㥞な目的の第几使用 されて以來，その利用は常に增加し棑なつた，そして，今 日於ては壓延並びて線引に俈つて生ずる複雜な變形組 織をX線を用ひて研究する際には全く缺くべからざる "ものであると考へられて居る.

優越方位の研究沉用ひられる極點圖上云ふの怯試料の

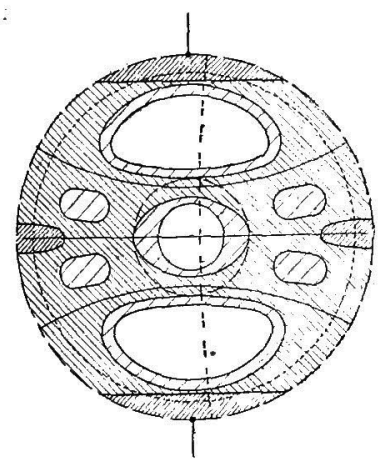

第 24 圖(31) 常溫㹂延に依つ 一厚さを $85 \%$ 減少された杴

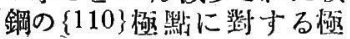
唯圆(32).

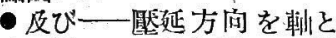
寸る單純な延件組織, 延面の法線を䡉とする單純

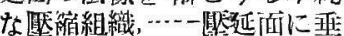
直に入㩆した X 綜に寺する

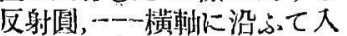
射した場合の反射圓 結晶粒內に於忊る一定の 指數の面 $\{h k l\}$ の總てひ 極點のステレオ投影であ る.それは低指數の面に 對してのみ，即ち等軸梨 の金屬に就ては $\{100\}$, $\{110\}$, 或ひは $\{111\} の$ 型式の面の何れか儿對し て, 又六方型の金屬に就 ては通常 (0001) 面**に對 してのみ描記される. 結

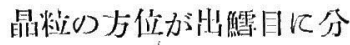
布して居るとてろの試料 几於ては $\{h k l\}$ 面汇對す る漇線は參考球の裴面を 到万所同一の頻隻で異く ととになるが, 併し或る 方位が優越してて居る場合にはその交點が或局限された面

* 東北帝國大學助教授，全屬材料研究所員，

(28) F. Wever, Mitt. Kaiser Wilhelm Inst. f. Eisenforschung, 5 (1924), 69; Z. Phys., 28 (1924), 69.

** 六方格子に於ける Miller の指数に就ては末尾の被埤 を参照されたい
䖽に於てのみ稠密になる．球のステレオ投影，即ち極點 圖、に於ては，極墨の密度が最も稿密を面積を多數の斜線

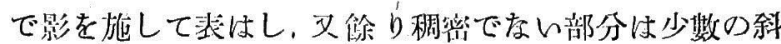
線で影を施すのが通例であうて，斯様にして通常密度の 程度を2〜4段澏别する(第 24 图を見よ). 猶, 地圆上 の等高線の樣に，一䇥の頻度の點を通る等頻度線を描时 代一渞定量的な裴示が可能である。この極點の相對的 な頻度は X 線の迎折圖形に於ける對應する環の哭さ

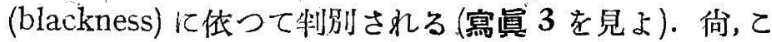
の場合には吸收效果の正確京测定を行ひ，そしてそれに 對して慎重孛補正をなすべきであるが，併し當面の間題 に於ては熙さの $2 \sim 4$ 倍の程度の相遼を肉腿で判斷すれ ば十分である，以下に於ては，まず X線圖形から得られ る結果を極點圖江變撸する方法に就て述へよう。

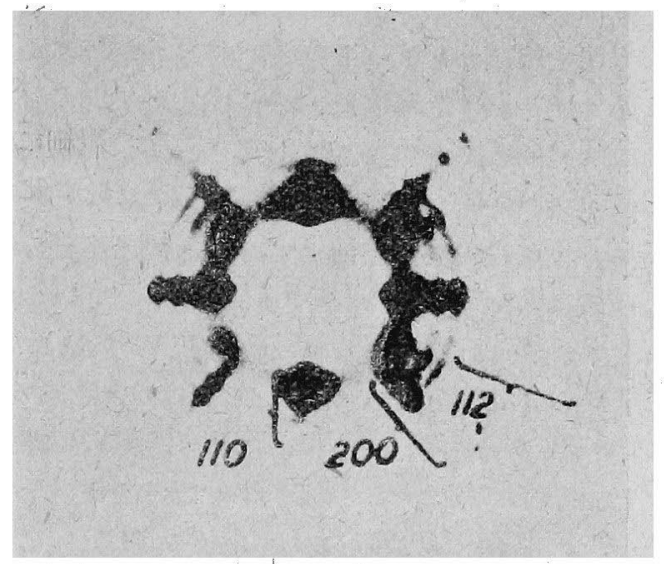

寫值 3 常溫厚延された鋼の X線廻折圖形

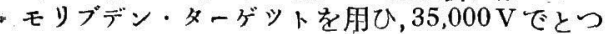
たおの，主要な Debye 環の指整が示されてある

(1) 極點圖の描記

第一に，X線越折圖形之極黔圖之の間に存在する簡單 を且つ直接的な關係を第 20 圖侸つて說朋しょ5。結 晶阇から反射された X 線の束はフィルム上に $\mathrm{S}$ なる哭 を作る.その結昆面の法線は參洘球を $\mathrm{P}$ 點で賁ぬくが, $\mathrm{P}$ 點は又投影面上の $\mathrm{P}^{\prime}$ 點にステレオ的に投影される。大 射線束，反射線束，及で反射面の極點は總て重線に對して ひなる俏度丈け傾的た一平面內に㐫る。圖に於ける如く， フイルム及で投影面が入射線束に對して画直に置かれて ある場合には，投影山心の周りの角度關係はその儘フィ ルム上のそれに維應するととは容易に諒解されるであ らう. 
$\mathrm{X}$ 線が反射を起す柡な，結晶面への入射角 $\theta$ は Bragg

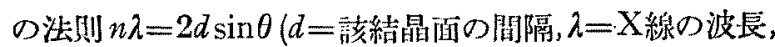
及び $n=$ 整敌)に依つて沈定されるから，反射し得る總て

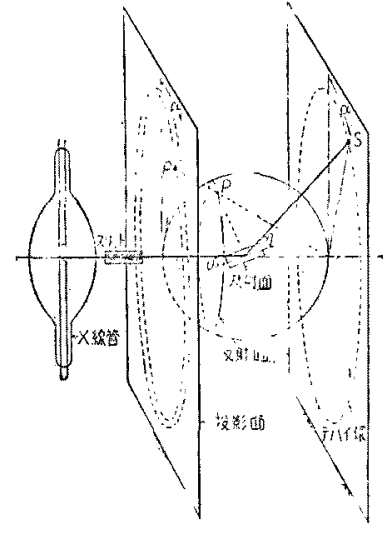

第 20 圆結晶面, 迴折訚形及び ステレオ投影間の關係。 極點 $\mathrm{P}$, 迴折像 $\mathrm{S}$ 及び投影 $\mathrm{P}^{\prime}$ は 稳七入射 X線をを含む一つの 平面間にある の面の榓點は入射線に 齛して $90^{\circ}-\theta^{\circ}$ なる 等の任度文け傾いて居 る譯であつて, 從つて それらの面の極點之參 考球との交默は一つの 圓を作る。この反射圆 (reflection circle) 之呼 ばれる圆は投影上に於 ては中心のX線束か ら $90^{\circ}-\theta^{\circ}$ 融たつて居 る、斯樣にして, 殒點 圆に於ける偏角と動徑 が让定される譯であ る。
單一の趣折環 (Debye 環) の强さの極大は總て極點圆 に於ては單一の反射圆上に描記される，反射圓が栖照圆

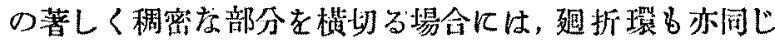

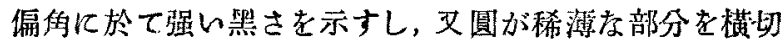

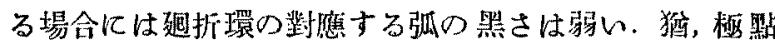
圖上の真の面積䡉袁を決定するには，投影を掩ふ絧目を 作るところの反射圓の組を描記することが必要である。

それには試料の䝨斜を $5^{\circ}$ 乃至 $10^{\circ}$ 置き几變へて迥折環 の舄真をとればよいのであるが，その露出の數は必裂に 應じて 5 から 20 回迄位に變化するであらら(29).

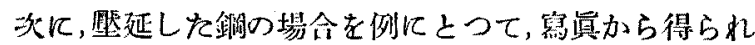

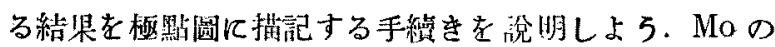
特性 X 楾 $\left(\mathrm{K}_{a}\right)$ を用ひを場合には，地鐵の $\{110\}$ 面に伎 ろ趩析は $\theta=10^{\circ}$ で起るから，從つて反射圓は極點圆の 中心から $90^{\circ}-\theta^{\circ}=80^{\circ}$ 踓れて存在する。若し最初の寒 真を試料の表面に重直に X 線を投射して撽れば，投影に

(29)振動フィルムの装盈を用ひれば定常フイルム型で多数

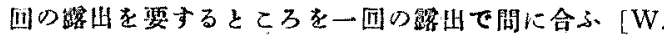
P. Davey, Phys. Rev, 23 (1924), 764; T. A. Wilson, Gen. Elec. Rev., 31 (1928), 612; O. Kratky, Z.Krist. $72(1930), 529$; C. S. Barett, Trans. A. I. M. E., 93 (1931), 75; Metals and Alloys, 18 (1937), 13.]. 又, 路

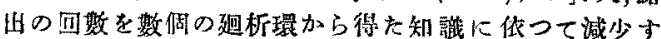
る事が出来る。例一ば，(211）の超析環の極大を調へ， 乙社等の極大を生ずる篇の $\{110\}$ 或ひは $\{100\}$ 極點の 位置を計算して，その結果を $\{100\}$ 或ひは $\{110\}$ の極點 圆上に描記するのである。この方法の詳細に就ては W. P. Davey, A Study of Crystal Structure and its Applications, New York (1934), McGraw Hill; C. J. Post, 2. Krist., 90 (1935) 330 を照されたい.
於てはえの表面は基圓として，刃反射圆はそれに共心な 圆として現はれる，次に，試料老垔值軸(第20圆に於ける 縱の方向)の周りに，例一ば $30^{\circ}$ ，迴薄して(X 線の入射方

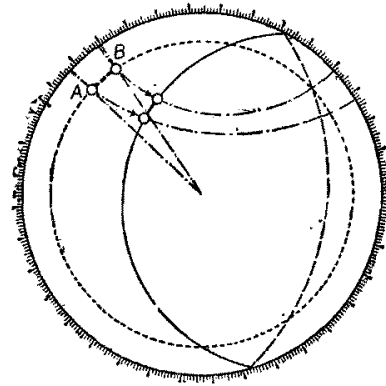

第 21 圆 栖點圆の描記.---

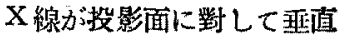
な埸合の区射圆，一专び ーー一試科の表面安投影面之 した場合の区射圆
向から見を場合に試料の 右端をち側に趣轉する)， そして再ひ寫其をとつた としよう.そてでまず, 前之同樣江投影面をX綵 に垂直にとりそして反 射圆を同心圆にして,そ の結果を描記すると，第 21 圆炕示す如くになる。 そてでは反射圆は點線の 圆で、叉，Debye 環の强 さの極大の限界はA及び B で示されて扂る.ところで,ての場合には試料の表面 が投影面儿對して $30^{\circ}$ 偭斜して居るのであるから，試料 の表面を投影面之する極點圆を描記する第にはての場合 の賽驗絬果を總て逆に右倒て $30^{\circ}$ 迴㸾しなりればならな 々. 乙の迴博を行ふっには，Wulff の網考用ひて反射圆上 う各點索その緯線に沿ふて $30^{\circ}$ 丈け右側に動かせ代上 n. その手續きは第 21 圆に示す如くであつて，そてでは 迴㮦を行つを後の反射圆の位置を實線で，又そ.の右側の 部分は負の牛球老通るから破線で措いてある。ての手縝 き試料の種々の setting 亿就て行へば，極黔圖上の面皘 籁圍が明確に決定されるのである。

正规の setting 亿㞔した時の反射圆の組の位置, 即ち 試料の表面を投影面としを際の位置，を示す圖面 (chart) 一てれ反射圆圆 (reflection circle chart)と名付けるー を作つて置けば上述の指記を行子、際の面倒が大部分省け

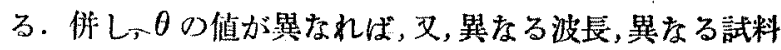
の物筫，並びに異なる反射面に㮣して，異なる反射圆圆が

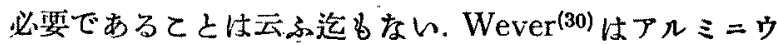
$\Delta の\{001\}$ 面及ひ $\{111\}$ 面加ら反射する銅の $\mathrm{K}_{\alpha}$ 線汇對 する反射圆圆，及び鐵の $\{110\}$ 面から反射する鐵の $\mathrm{K}_{\alpha}$

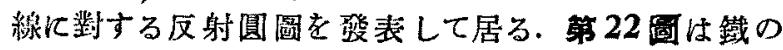
$\{110\}$ 䣶から反射するモりブデンの $\mathrm{K}_{\alpha}$ 線に對する反射 圆圖 $\left(\theta=10^{\circ}\right)$ であるが，てれ的ては反射园を $0^{\circ}$ から $90^{\circ}$ 迄 $5^{\circ}$ 置き几描記してある. 總ての反射圓の上の偏

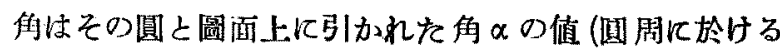
數）を附した緯線との交點に位つて與へられる，反射圆 が裹り牛球も上にある場合には點線で示されて居るが，

乙れに對してを $\alpha=$ 一定の線は表牛球に於けると同一の

(30) F. Wever, W. E. Schmid, Mitt. K.-W.-I. Eisenforsch., 11(1929), 109: F.Wever, Trans. A.I.M.E., 93(1931), 51. 
のが朋ひられる:ての反射圆圖老用ひて，鐵からの

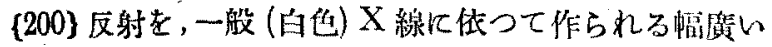

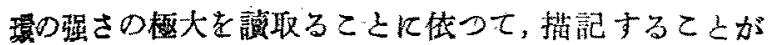

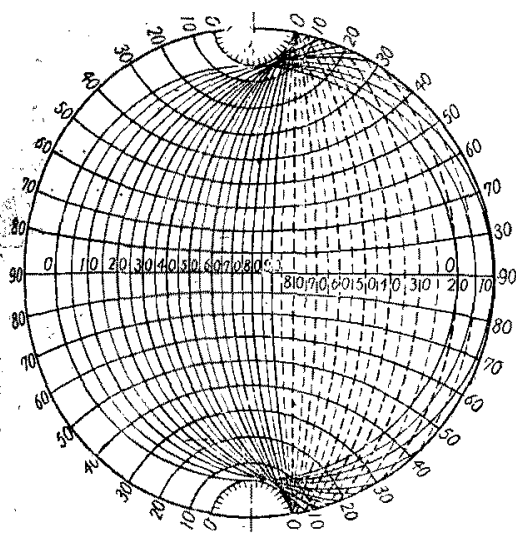

第 22 圆 鐵の(110)面加的区射古五 リブデンのKa總に對する反射圆 $\theta=10^{\circ}$.

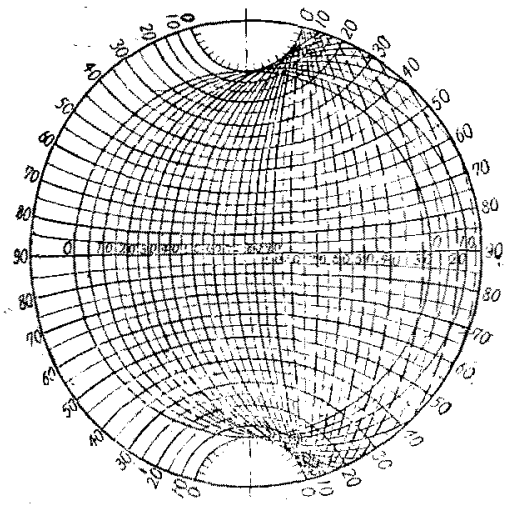

第 23 圖 鐵の (200)面から反射省

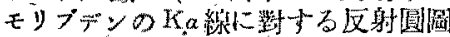
$\theta=14^{\circ} 21^{\prime}$

川來るが，それ は, $30 \sim 40 \mathrm{KV}$ で撹作されるX 線管から出る一 般 $X$ 線 $0\{200\}$ 反射心最名强几 部分は $\theta=10^{\circ}$ の近傍にある らである・又， $\{110\}$ 面加ら口 一般 $\mathrm{X}$ 線の反 射の强さの極大 は $\theta=7^{\circ}$ 老中心 として局て，そ して栖點圖索描

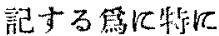
邀虽して居る が,それは\{200\} 反射が重蜋せ ず, 叉往及重要 な事唡となると ころの䐎さの僅

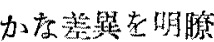
凡示すからであ 当, 估, 鐵加ら のモリブデンの $\mathrm{K}_{\alpha,} \varnothing\{200\}$ 反

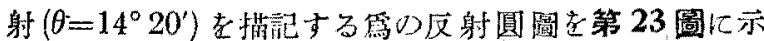
Lた.

第 22 及び 23 圆に示した反射圓圖の傎之底の近傍の面

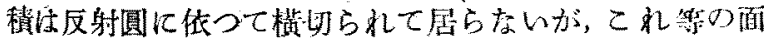

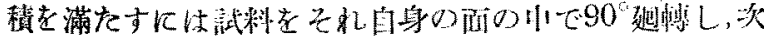

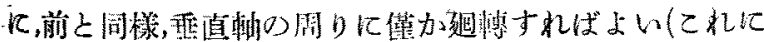

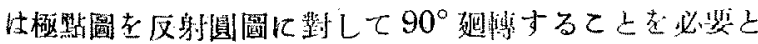

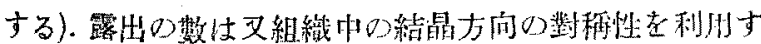
ることて依つて減少することが出棑る，例へ代，盟延さ

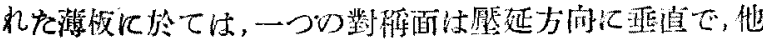

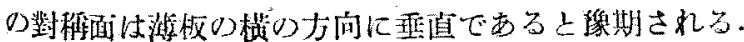
件し，常にそれ等を假定することをしないで知張り一應 閶へててみるがよい。(31)

軟銅索壁延してその厚さを $85 \%$ 減少させた後簿刢に

(31) 例へば M. Gensamer, R. F. Mehl, Trans. A. I M. E., $120(1936), 277$ 参照.
依つて表面層索除去した埸合の極點圖は的 24 圆に示す

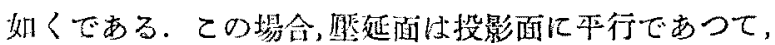

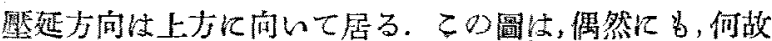

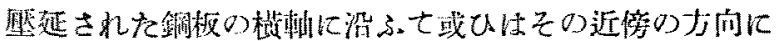

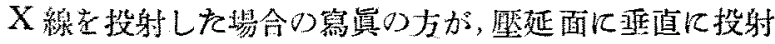
した場合のそれよりる，優越方位を著しく現はすか，祝

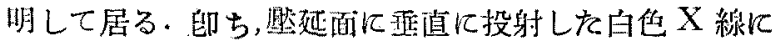

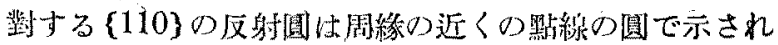
て居るが，併してれは强さが非常に異交つて居る籍圆を

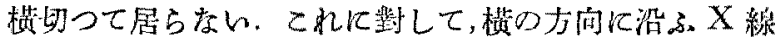
飞路する反射圓は投影中心の近傍を頂から底远延びて居 る點線として現はれて居り，そして强さが極大及び極小 である㥞な部分を通つて居るが，ての兩部分は $\{110\} 0$ 迵折環江於て特㐳著しい極大及で極小老作るのである。

\section{(2) 變態及び折出の研究に於ける極點圆}

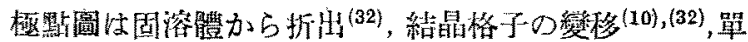
結昆の再結晶(33)，共折反碓(34)，包晶反應(35)，或ひは酸 化 ${ }^{(36)}$ に上つて出來る新しい繥晶と元の地の結晶との間

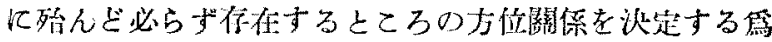

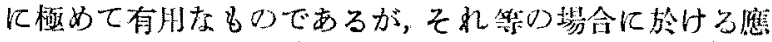

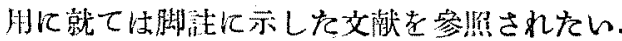

(3) 極點圖の解釋に就て ${ }^{377}$

\section{a. 理想的な方位}

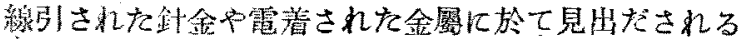

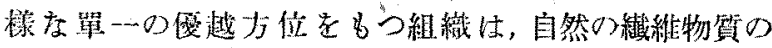

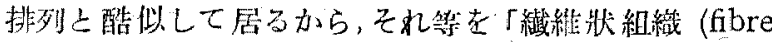
structures)jと胢ぶのは誠に適當存名前であると思ふ。 それは「瀻維斬」(fibre axis)に平行な一つ結昆學的力

(32) C. H. Mathewson, D. W. Smith, Trans. A. I. M.E.

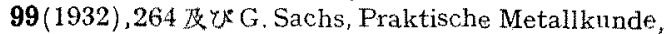
3. Teil, Wärmebehandlung, Berlin (1935), Springer 松照.

(33) C. S. Barett, H. F. Kaiser, R. F.Mehl, Trans. A. I. M. E., 117(1935), 39; W. G. Burgers, J.C. M. Basart, Z. Phys., 51(1928), 545; 54(1929), 74; W.G. Burgers, P. C. Louwerse, Z. Phys., 67(1931), 605; Metallwirtsch., 11 (1932), 251 ; W.G. Burgers, J. J. A. Ploos van Amstel, $Z$. Phys, 8 (1932), 43.

(34) G.Sachs, Praktische Metalliunde, 3.Teil, Wärmebehandlung, Berlin (1935), Springer; R. F. Mehl, D.W. Smith., Trans. A. I. M. E., 116 (1935), 330.

(35) A. B. Greninger, A. I. M. E. Techn. Publ. No. 757 [Metals Techn., 4 (1937)]

(36) R.F. Mehl, E.L. McCandless, A.T.M.E. Techn. Publ. No. 780. [Metals Techn., $4(1937)$ ]; R. F. Mehl. E. L. McCandless, F. N. Rhines, Nature, 134 (1934), 1009.

(37) Laue 笉焦のアスデリズム (asterism) の解釋に就ては

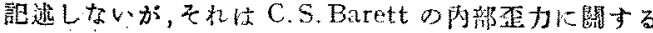
綜合赫㫮 [Metals and Alloys, 5(1934)，131，154，170 196，224]に總括されて居る加巨贸照されたい。 


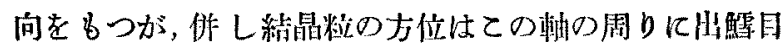

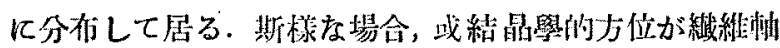
に平行である栐な理想的な方位 (ideal orientation) 孝標 準にとり，それからの偏倚に依つて組織を記述すると都

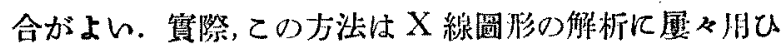
られ，そして針金の場合に於て特に有脚るのである。 併し乍ら，Wever (38) は複雍な變形の機桠を解析する埸 合にこの記述法な不完全な且つ懓昧な結県に導くと云つ て反對し，そして極點圖てそ觀测されを絬果を公平に泰 示するから，斯樣な機棈の研究に對してより安全な上臺 を成するのでるる强調して居る。

以下，多數の例老簡單に考察し午ら極點圖の解釋に就 て說明しょ5.

\section{b. 正組跑}

厘莚組織 (rolling textures) は, 壓縮組織 (comperession textures) と延伸組織 (tension textures)の重曡したるの

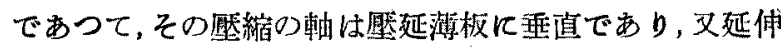
の軸は娾延方向に本行である，とすると最もよく說明さ

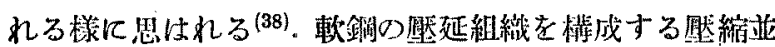
びに延伸組織は第 24 㘣に示す如くである.そこには，

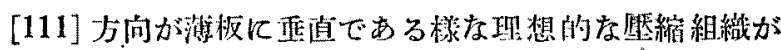
點線で描かれた二つの共心の圆一一つは中心から $35^{\circ}$

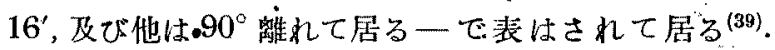
又. [110]方向が厴延方向に平行でする㥞存理想的な延

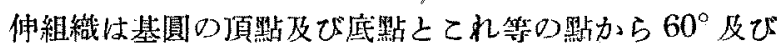
$90^{\circ}$ 離れた實線で裴示されて居る。乙れ等の理想的な組 織が極點圖の椅泌な部分を横切つて房ることに注意され

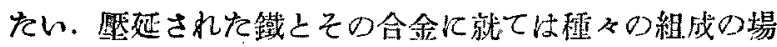

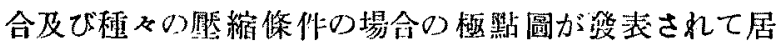

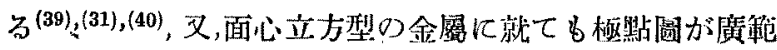
園に脚ひられて居るが(41)，併しての場合は延伸及び琞綃

(38) F. Wever, Trans. A. 1. M.E., 93 (1931), 51.

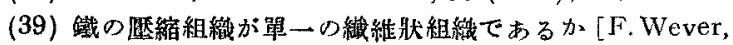
Z. techn. Phys., 8 (1927)，404]，或ひは [111] 及び [100] の雨方向共朕縮軸に一政して居る漛な二重の組 織であるか [小野, Mem. Coll. Eng. Kyushu, Imp. Univ., 3(1925)，195，267] 儿就てはま梑決定されて居 らない，何，恹延された鋼の組織は二重組織でない。

(40) G. Kurdjumow, G. Sachs, Z. Phys,, 62 (1930), 592; C.B. Post, Trans. Amer. Soc. Metals, 24(1036), 679; M. Gensamer, B. Lustman, A. I. M. E. Techn. Publ., No. 748 [Metals Techn.,Sept.(1936)], D.McLachlan, W.P.Davey, Amer. Soc. Metals, Reprint, Oct:(1936) ( Fe-Ni 合余); C. S. Barett, G. Ansel, R. F. Mehl, A. I. M. E. Techn. Publ, No. 813 [Metals Techn., Aug. (1937)] ( Fe-Si 合金).

(41) E. Schmid, G. Wassermann, Handb. d. Phys. u. Techn. Mechanik, Vol. 4, S. 319, Leipzig (1931), Barth; L. Herrmann, G. Sachs, Metallwirtsch., 13 (19.34), 745; G. V. Vargha, G. Wassermann, Metallwirtsch., $12(1933), 511$.
組織が共に，二つの方向が織維輣と一致して居るところ

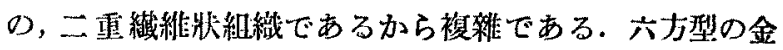

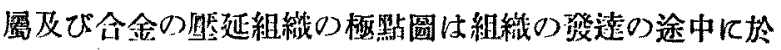
ける双晶形成の意军を解朋し，又溥板の表面と內部の組 織を比較する上に於て特に有用である(42). 變形組織と單 絬晶の變形機椿との關係は六方型の金屬几於ては全く面

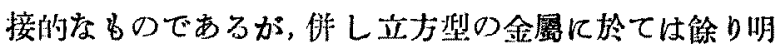
確ではない，倞し乍ら變形組織內の主要な方位老安定な ๖のとし，そして變形の絈果結晶粒の方位がそれに近つ いて行く，上洘へるのが最も帘當である樴に思はれる(43).

\section{c. 表面照形組織}

切削及び壓延に依つて作られる表面組織の極點圆に就 ては二、三の例を舉げ得るに過をない，常溫壓延された 亞雓 ${ }^{(44)}$ 及びその合金 ${ }^{(45)}$ の表面組織は內部の組織とは巽

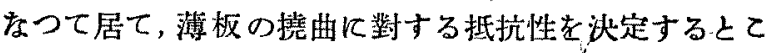
ろの重要な因子である。

常溫黙延された軟鍓の表面は乙れ再結晶組織に似を

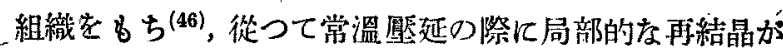
起るるのと考へられて居る. 叉, 形削盤 (Shaper) で切㓩

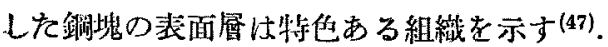

\section{d. 强度の押拔きに啃つて作られる組緎}

最近，强度の押拔さ学受けた薄板の組織の研究が，「極

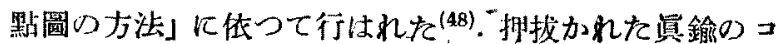
ップ(cup)の長さの方向に沿ふ種々の斷面に就て X 線 鼠真をとり，そして極點圖老描記したとてろ，塑性流動の 方向に剅應して斷面に依つて組躘は異なるが, 併し常に

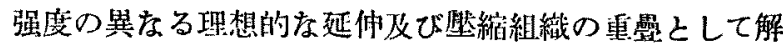
析ずることが出來を，例入ば， cup の底面の中心に於り

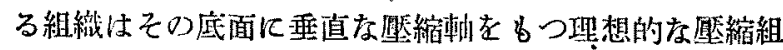
織であるが，てれは押拔きに依つて脽板が薄くなる際の 塑性流動の樣子加ら期待されるとてろである。乙れに反 して, cupの上緣に於ては切線方向に望縮軸をるつ殆ん

(42) E.Schmid, G.Wassermann, Metallwirtsch, 9(1930), 698; Z. Metallk., 23 (1931), 87; Metallwirtsch., 10 (1931), 735; M. L. Fuller, G. Edmunds, Trans. A. I. M. E., 111 (1934), 147; V. Cagliotti, G. Sachs, Metallwirtsch., 11 (1932), 1; M. A. Valough, Metallwirtsch., 11 (1932), 165;W. G.Burgers, Metallwirtsch., 14 (1935), 285

(43) M. Palanyi, Z. Phys., 17 (1931), 42; G. Sachs, E. Schiebold, Naturwiss., 13 (1925), 964.

(44) E. Schmid, G. Wassermann, Z. Metallk., 23 (1931), 87.

(45) G. Edmunds, M. L. Fuller, Trans. A. I. M. E., 99 (1932), 175.

(46) M. Gensamer, B. Lustman, A. I.M. E, Techn. Publ., No. 748 [Metals Techn., Sept. (1936)].

(47) M. Renninger, Metallwirtsch., 13 (1934), 889.

(48) L. Herrmann, G. Sảchs, Metallwirtsch., 13 (1934) 745 . 


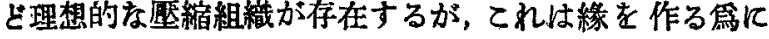

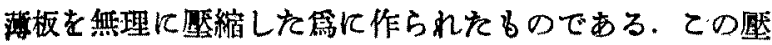
樎組織は側面の上方の部分一率に，强度は弱いが，存在し て，且つ垂㨁な (cup の軸儿平行な) 延伸軸を当つ延伸組 織と重舅して居る.

\section{e. 再結晶組識}

㻺延及び線引した金屬を再結晶せさた後に見出だされ る伐越方位に就てはまた゚解明されて居らない，壓延され たものに於ける優越方位は極めて複雜であつて，鐵(49)， 鐵一=ッケル合金 ${ }^{(50)}$, 軟銅 ${ }^{(51)}$ ，鐵一珪素合金 ${ }^{(52)}$ ，マグネ シウム ${ }^{(53)}$ ，亞鉛 ${ }^{(54)}$ ，及びアルミニウム ${ }^{(55)}$ K就て行はれ た如く、極點图を朋ひずには明がすることは到底抂め ない.

(49) G. Kurdjumow, G. Sachs, Z. Pbys., $62(1930), 592$.

(50) W. G. Burgers, J. L. Snock, Z. Metallk., 27 (1935), 158.

(51) M. Gensamer, B. Lustman, A. I. M. E. Techn. Publ., No. 748 [Metals Techn., Sept. (1936)].

(52) C. B. Barett, G. Ansel, R.F. Mehl, A. I. M.E. Techn. Publ., No. 813 [Metals Techn., Aug. (1937)].

(53) E. Schiebold, G. Seibel, Z. Phys., 69 (1931), 458.

\section{[禣遗]六方格子に於ける面の Miller の指數}

立方格子に於ては，便宜上，その座標軸として，第25日 に示寸如く，互ひに $120^{\circ}$ の角度考む 3 個の軸， $\mathrm{x}, \mathrm{y}$ 及

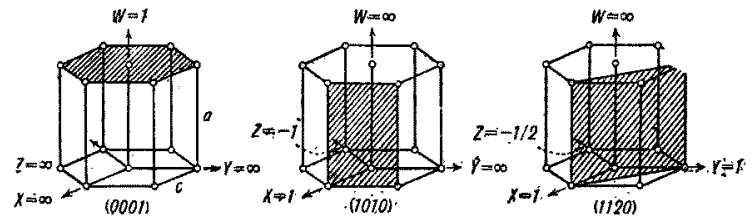

第 25 圆 六方格子の面の Miller の指教 主㴗な面と單位軸長 $a$ 及び $c$ との關倸

び $\mathrm{z}$ とそれ等に垂值な 1 個の軸 $\mathrm{w} の 4$ 倜の軸をとる. $\mathrm{x}, \mathrm{y}$ 及び $z$ 軸の單位軸長は共飞 $a$ ，そして $\mathrm{w}$ 軸のそれは。 cである. 從つて, (V. 4) に於て述べたとてろに依つて， この格子の主姴な面及びその miller の指數は圖に示す如 くになる譯でする.(完)

(54) R. Straumann, Helv. Phys. Acta, 3 (1930); 463; M. L. Fuller, G. Edmunds, Trans. A.I.M. E , 111(1934), 146.

(55) E.Schmid, G. Wassermann, Metallwirtsch., 10(1931), 409 .

資料

而酸鋼 (僠譯)

[H. J. Rocha, Chem. Fabrik, 13 (1940), 379]*

森岡進**譯

耐酸銅を管理䋁制するといふてとはその化學的乃至酎 触的性質を十分利用することに外ならをい.。かるる見地

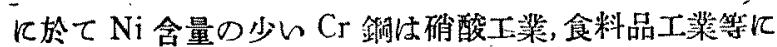
於て廣く用ひられ，中性或は酸性の酸化性狀况のもとで

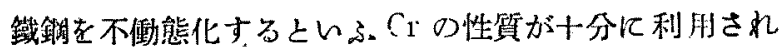
てわる。しかし硫酸や籃酸が保在するために Ni, Mo, 或

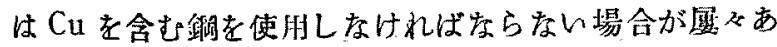
る、乙の場合にはてれ等の有效な合金成分老浪费しない

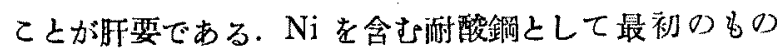

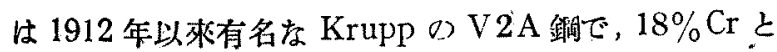
$8 \% \mathrm{Ni}$ を含むものである。このV2A絧に，或は時には その Cr 量及ひ Ni 量孝變へて，適當量の Mo 或は $\mathrm{Cu}$ 加へると特别な使用目的に適合した耐酸鐝が得られる.

** 東北策國大照助数授，金圆材料研究所員.

* Tech. Mitt. Krupp Forschungsberichte, 3 (1940), 191. K与揭載さる。.
種々の使用目的に對しててれ等の銓を選擇するには勿 論それ等の化學的性質索正碓に知つてわることが必要で ある.このことは侵強劑との開に起り得る反應が色々あ る場合には一層そうである。例入ば鐵鍋は亞鉛のやらに

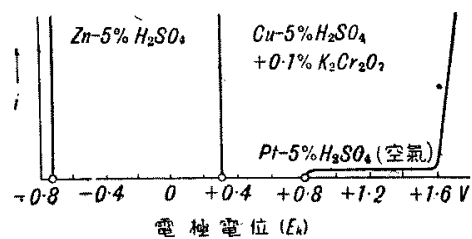

第 1 圖 電流密度一電位曲楾 水素学遊離して酸 と作用するてと b, 白金のp5に 酸け中で侵されな いであるてとも。 或は銅之同樣に值 接酸化のもとに酸素を供給する酸に溶けることも出來 万.(第 1 圖寥渢)

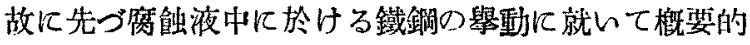
に述べる.乙れは電氣化學的に述ぶるのが最もよいし かし電位のみではどらしても多種の現象を整理するのに 